Page, A.D., Hill, J.S., and Gilbert, G. (2012) North Carolina Sexual Offender Legislation: Policy Placebo? Journal of Offender Rehabilitation, 51(3): 115-134. Published by Taylor \& Francis (ISSN: 1540-8558). DOI:

10.1080/10509674.2011.623219

\title{
North Carolina Sexual Offender Legislation: Policy Placebo?
}

Amy Dellinger Page, Julie Sprinkle Hill, and Griff Gilbert

\begin{abstract}
Current legislation at the state and federal level is largely based on the premise that we can best protect children by prohibiting sexual offenders' access to children through the use of residency restrictions, employment sanctions, and community notification. While well intentioned, these policies are short sighted and based more on public misperceptions than empirical research. In this study, the authors assess sexual offenders' perceptions of residency restrictions in the state of North Carolina. The study population was comprised of a nonrandom sample of 231 adult sexual offenders from 11 outpatient sexual offender treatment sites in North Carolina. The majority (151) of sexual offenders stated that housing restrictions do nothing to prevent them from reoffending. More than half (135) indicated that no residency restrictions would serve as an effective deterrent. These findings indicate the need for a more comprehensive approach to the community management of sexual offenders.
\end{abstract}




\section{INTRODUCTION}

The rationale undergirding official North Carolina efforts to control the post-adjudication residency of adult sexual offenders seems to be sound, utilitarian, and defensible. That rationale is similar in form and essence to what has been codified in jurisdictions across the United States. However, its effect in North Carolina has fallen short of its promise-and may be judged as more placebo than remedy. While well intentioned, the policies that have evolved have been incomplete and short sighted-a series of political responses and validations based more on public misperceptions than on empirical research. Research indicates the following:

1. Sexual offenders statistically have a low recidivism rate-far out of proportion to public perception.

2. North Carolina's residency restriction, requiring living at least 300 feet from child congregating areas, provides little more than a false sense of security ameliorating public fears.

3. Stringent residency requirements in practice produce some significant unintended results: For example, available housing is more than frequently located in the least "desirable" neighborhoods, depressing environments engendering fear and dangerous isolation. Such surroundings enhance rather than mitigate incidences of recidivism.

4. There is no empirical evidence of a correlation between the proximity of sexual offenders' residences and increased recidivism.

5. The concept of management boards (defined and discussed later in this article), properly constituted, mandated, and transparent, seem to be more logical and effective vehicles for responding both to the general and the aberrant, idiopathic, potentials and incidents of reoffending.

\section{Rationale for State and Federal Requirements}

Protecting the public, particularly children, from sexual offenders has motivated lawmakers nationwide to craft increasingly stringent policies regarding employment, residency restrictions, registration, and community notification. The Jacob Wetterling Crimes Against Children Act, the Sexually Violent Offender Registration Act, Megan's Law, and the Adam Walsh Act have all increased restrictions and sanctions for sexual offenders (White, 2008). Even though laws designed to track and limit the movement of offenders began over half a century ago (Norman-Eady, 2007), their effectiveness remains debatable and significant questions pertaining to sexual offender legislation persist. All of the legislation aimed at restrictions of where sexual offenders live and work is based on offenses committed by strangers. While tragic in their consequences, these cases are not representative of the overwhelming majority of sexual offenses. Most sexual offenders (93\%) are known to their victims (Snyder, 2000).

The current study examines implications for sexual offender policy based on an exploratory analysis of adult registered sexual offenders undergoing treatment in the state of North Carolina. This study is limited to the statutory and implementation parameters of North Carolina's response to 
the postadjudication residency requirements for sexual offenders. While there is some limited reference to the practices of other states, its scope will not be national. However, some extrapolation from our findings may be useful beyond North Carolina. A larger study, examining the practices and results of each of the other states, would no doubt produce conclusions beneficial to all. That is the subject for a future enterprise.

\section{LITERATURE REVIEW}

Currently, 30 states mandate residency restrictions for sexual offenders (Meloy, Miller, \& Curtis, 2008; Bonnar-Kidd, 2010). These restrictions prevent offenders from living in areas where children congregate, such as schools, daycares and public parks. Restrictions vary by state from 300 to 2,500 feet (Levenson \& Cotter, 2005; Agudo, 2008), with the average being around 1,000 feet (National Conference of State Legislatures, 2006). North Carolina, where the current study occurred, has one of the least restrictive residency laws at 300 feet (NCGS 14-208.5).

Despite the 300-foot North Carolina stricture, the belief that residency restrictions create a safe environment for children is a misperception. While offenders may be prohibited from living and working within a certain distance where children are known to gather, offenders are not prohibited from venturing into these areas for doctor appointments, to visit family and=or friends, or to patronize a store. In addition, studies indicate $90 \%$ of sexual crimes against children are perpetrated by someone known to the victim (Bagley, 2008). Therefore, residency restrictions may provide a false sense of security rather than genuine protection from harm.

Like residency restrictions, community notification has also been utilized as a method to protect children from possible victimization. Community notification works on the assumption that if parents and neighbors are aware a sexual offender is living in the area, they will be more vigilant and protective of their children, reducing the opportunities for an offender to victimize children or other neighborhood residents. Some data supports the contention that community notification reduces recidivism (Baronski, 2005). However, recidivism (as measured by a combination of rearrest and reconviction data) among sexual offenders is relatively low (Arizona Department of Corrections, 2000; Bureau of Justice Statistics, 2003; Sample \& Bray, 2003, 2006; Harris \& Hanson, 2004; Hanson \& Morton-Bourgon, 2005; State Department of New York Corrections, 2005; Valentine \& Huebner, 2006; Gwyn, 2007; Ohio Public Safety, 2007; White-Carns, McKelvie, \& Cohn, 2007; Huenke, O'Connell, Price, \& Weidlein-Crist, 2007; Zgoba, Veysey, \& Dalessandro, 2010; BonnarKidd, 2010). Gwyn (2007) noted that sexual offenders in the state of Tennessee were approximately half as likely to reoffend as perpetrators of other crimes. Similarly, Valentine and Huebner (2006) found sexual offenders to have the lowest rates of recidivism for criminal offenders in the state of Missouri. Studies conducted in Ohio (Ohio Public Safely, 2007), Alaska (White-Carns, et al. 2007), New York (State Department of New York Corrections, 2005), Delaware (Huenke et al., 2007), and Arizona (Arizona Department of Corrections, 2000) also reported similar results. These consistent 
findings regarding low rates of recidivism among sexual offenders raise questions about the necessity and cost efficiency of community notification, registration and residency restrictions.

\section{Consequences of Residency Restrictions}

Residency restrictions often lead to significant negative repercussions and unintended consequences, referred to as collateral consequences, which make it more difficult for offenders to reintegrate into the larger social fabric. Specifically, residency restrictions can lead to housing barriers (Grubesic, Mack, \& Murray, 2007; Mercado, Alvarez, \& Levenson, 2008; Chajewski \& Mercado, 2009), a decline in housing quality (Mustaine, Tewksbury, \& Stengel, 2006) and difficulty securing employment (Harrison \& Schehr, 2004; Tewksbury \& Zgoba, 2010).

Current residency restrictions for sexual offenders limit housing availability, particularly in urban, and to a lesser degree, rural areas (Chajewski \& Mercado, 2009). Housing shortages can contribute to a transient lifestyle or long-term homelessness among offenders (Levenson, Zgoba, \& Tewksbury, 2007; The Council of State Governments, 2007). Law enforcement officials

may have difficulty tracking offenders as they become homeless or experience chronic transience (Brock, 2010).

Residency restrictions can also prevent an offender from living with supportive family and=or friends if the home is located too close to a school, park, and=or day care facility. In conjunction with a correlation between housing instability and the commission of new crimes (Meredith, Speir, Johnson, \& Hull, 2003; Schulenberg, 2007), these blocked avenues of social support (Levenson, 2009) bolster the tentative conclusion that present residency restriction legislation may actually lead to increased reoffending.

In addition to difficulty securing housing, many offenders will experience a decline in the quality of their housing (Mustaine et al., 2006). Offenders are more likely to find housing in dilapidated, high crime and economically depressed areas. Difficulty finding employment can contribute to declining social mobility and limited housing options. Many sexual offenders are prohibited from working in areas where they will have access to children (Tewksbury \& Zgoba, 2010) and find the only employers willing to hire them pay below a living wage. Financial and emotional hardships (Levenson \& Cotter, 2005; Tewksbury, 2005; Tewksbury \& Lees, 2006; Levenson, 2008), depression, anger, and hostility (Zevitz, Crim, \& Farkas, 2000; Zandbergen \& Hart, 2006), may all contribute to an increased risk of reoffense. Each of these variables is negatively affected by existing sexual offender legislation.

\section{Proximity and Recidivism}

The most compelling argument for revising current sexual offender legislation can be found by examining the relationship between proximity and recidivism; geographic proximity to areas in which children congregate 
has not been shown to increase rates of recidivism among sexual offenders. In fact, studies exploring the connection between geographic proximity and recidivism have found no association between how close an offender resides to a school, park, bus stop, and=or day care facility and increased rates of recidivism for new sexual offenses (Minnesota Department of Corrections, 2003; Colorado Department of Public Safety, 2004; Levenson et al., 2007).

Present restrictions also label offenders as social and community outcasts, making it more difficult for offenders to develop the social networks and support needed to prevent reoffense (Bagley, 2008). Family members may also experience negative ramifications, such as social ostracizing, due in part to the public perception that sexual offenders are unlikely to be rehabilitated (Payne, Tewksbury, \& Mustaine, 2010). Since the majority of sexual offenses are committed by family members or someone closely known by the victim, mandatory registration may contribute to the fear that "everyone will know" what happened to their child and parents may decline to bring it to the attention of law enforcement. Similarly, others may fear that if they report the perpetrator, they will be removed from the family, resulting in economic hardship (Lane Council of Governments, 2003). However, there is little empirical evidence that sexual offender registration and=or restriction positively or negatively impacts reports of child sexual abuse.

Conversely, there are positive aspects of community notification, residency restrictions and registration. This legislation promotes collaboration by law enforcement personnel across counties, municipalities, and states, provides opportunities for education about sexual offenses to the larger community, and increases awareness about sexual offenses. However, current sexual offender legislation has not been shown to further reduce already low rates of recidivism (Adkins, Huff, \& Stagebery, 2000; New Jersey State Parole Board, 2007; New York State Division of Probation and Correctional Alternatives, 2007; Vasquez, Maddan, \& Walker, 2008; Levenson, Letourneau, Armstrong, \& Zgoba, 2010; Zgoba et al., 2010) or to be cost effective (Lane Council of Governments, 2003). In addition, a survey of public perceptions revealed that most citizens do not feel housing restrictions prevent reoffense (Schiavone \& Jeglic, 2009).

The current study examines implications for sexual offender policies based on a sample of adult registered sexual offenders undergoing community-based treatment in the state of North Carolina. The majority of current studies focus on states with more stringent residency restriction policies (e.g., 2,500 feet from schools and day-care facilities). The most recent revisions to North Carolina legislation prohibit sexual offenders from living within 300 feet of schools and day-care facilities. The authors sought to determine whether sexual offenders in North Carolina faced similar impediments to reintegration within a state with one of the least restrictive residency restriction policies. Though the results of the present investigation cannot be generalized to all sexual offenders, the study yields robust and promising information to add to the growing corpus of literature on the topic of sexual offender legislation and restrictions. 


\section{METHOD}

\section{Sample}

A nonrandom purposive sample ( $n^{1 / 4231)}$ was surveyed regarding their experiences with and perceptions of residency restrictions in the state of North Carolina. The authors used a nonrandom sample due to the difficulty locating and obtaining a high response rate from a random sample of sexual offenders who are also subject to residency restrictions. A letter describing the study was distributed during the 2009 quarterly meeting of the North Carolina Association for the Management and Treatment of Sexual Offenders. Clinicians interested in participating left contact information and an estimate of the number of adult sexual offenders under their treatment. The researchers then contacted the interested clinicians and mailed survey packets to their offices. Eleven outpatient treatment facilities across the state of North Carolina distributed survey packets to their group treatment clients.

\section{Procedures}

Each survey packet contained the survey instrument and a statement of informed consent. Participants were told their participation in the study was voluntary and they could elect not to complete the survey, with no repercussions. They were specifically advised they could place a blank survey in the envelope, seal it, and place it in the drop box to give the appearance of participation. The participants were further advised their responses would remain anonymous. They were informed that research staff did not have access to any names of individuals attending therapy sessions, nor would any characteristics of the treatment facilities be released. During the administration of the survey, no investigator, therapist, or probation=parole officer was in the room, minimizing the perception of coercion. Participants were allowed ample time to complete the survey. The clinician gathered the sealed envelopes and mailed them to the researchers.

This research was conducted in accordance with federal guidelines for the ethical treatment of human participants. The authors obtained approval from an Institutional Review Board and from the North Carolina Department of Corrections. The return of a completed survey was considered consent for participation.

\section{Survey Instrument}

The survey instrument was designed to measure sexual offenders' experiences with residency restrictions. The instrument was adapted (with permission from the lead author) from a survey used in previous research (Levenson \& Cotter, 2005; Levenson, D'Amora, \& Hern, 2007; Levenson, 2008) and was altered to measure requirements for North Carolina sexual offenders. The original instrument was administered in the states of Florida (Levenson, 2008) and Indiana (Levenson et al., 2007), which have more restrictive residency restrictions. Questions regarding housing, employment and living with 
supportive family members were included in the survey, with yes=no response options. Demographic and offense history information were also gathered. Finally, two open-ended questions regarding the efficacy of residency restrictions were included.

\section{RESULTS}

Approximately 345 surveys were distributed to 11 outpatient treatment sites across the state of North Carolina and 231 completed surveys were returned. The study had a $67 \%$ response rate.1

Of the respondents, $37 \%$ (86) were between the ages of 18 and 33, 37\% (85) were between the ages of 34 and 41, and 19\% (44) were between the ages of 50 and 65 (see Table 1). A total of 35\% (81) of the sample reported they were never married, while 24\% (56) were married and 26\% (61) were divorced. Approximately $10 \%$ (24) were either separated or widowed. Of the sample, 74\% (171) identified their race as White=Caucasian, 12\% (28) identified themselves as African American, 3\% (8) as Latino, 1\% (3) as Asian American, and 4\% (9) classified their race as other.

TABLE 1 Demographic Information

\begin{tabular}{lc}
\hline Demographics & Percentage \\
\hline Age & \\
$18-33$ & 37 \\
$34-41$ & 37 \\
$50-65$ & 19 \\
Marital status & 35 \\
Never married & 24 \\
Married & 26 \\
Divorced & 10 \\
Separated or widowed & \\
Race/ethnicity & 74 \\
White/Caucasian & 12 \\
African American & 3 \\
Latino & \\
Education & 31 \\
High school diploma or GED & 29 \\
Some college & 9 \\
Associates degree & 7 \\
Bachelors degree & \\
Income & 25 \\
Less than $\$ 10,000$ & 44 \\
\$10,000-\$30,000 & 25 \\
More than $\$ 30,000$ & \\
\hline
\end{tabular}

Almost 31\% (71) obtained a high school diploma or GED, 29\% (67) attended some college, 9\% (22) had an associate degree and 7\% (17) had a bachelor's degree. Nearly one quarter (54) of the sample earned less than 
$\$ 10,000$ annually, while almost $44 \%$ (101) earned between $\$ 10,000$ and $\$ 30,000$ annually; $25 \%$ (57) earned more than $\$ 30,000$.

\section{Victims}

Respondents indicated that $97 \%$ of victims were less than 18 years of age. Of the sample, 5\% (11) were 5 years old or younger, 25\% (58) were between the ages of 6 and 12, and 53\% (122) were between the ages of 13 and 17. A total of $33 \%$ (75) of respondents reported family members as victims, $42 \%$ (97) reported acquaintances as victims, and $24 \%$ (56) reported strangers as victims. In all, 73\% (168) reported offending against females and 17\% (38) reported offending against males.

\section{Experiences With Residency Restrictions ${ }^{2}$}

Nearly one quarter (56) of respondents had been attending their current treatment group for 6 months or less. A total of 19\% (43) were part of their current treatment group between 6 months and 1 year, 27\% (63) attended between 1 and 2 years, and 24\% (56) were part of their current group for more than 2 years. Only 14\% (33) reported being in treatment prior to their current treatment group, and half (19) were in community treatment programs.

Of the respondents, $21 \%$ (49) were "grandfathered," meaning they did not have to move from a residence because their offense took place prior to restrictions going into effect (see Table 2). A sizable minority was unable to live with supportive family members (45) or with family members who depend on them (66) due to the restrictions. Many (76) reported difficulty locating a residence that met restriction guidelines and some (55) reported landlords refusing to rent to them because they are sexual offenders. Nearly half (110) reported emotional difficulty and many (73) also reported financial difficulties due to the restrictions.

\section{Perceptions of Residency Restrictions}

Table 3 describes sexual offenders' perceptions of residency restrictions. Only around one third of respondents believe they are better able to manage their risk factors because they cannot live near a school (65) and that the restrictions are successful in limiting their access to children (73). Nearly three quarters (170) of respondents believe the restrictions do nothing to prevent offenders from offending again, and if they wanted to reoffend, the restrictions would do nothing to prevent reoffending (172). 
TABLE 2 Sexual Offenders' Experiences With Residency Restrictions

\begin{tabular}{|c|c|c|c|}
\hline \multirow[b]{2}{*}{ Item } & \multicolumn{2}{|c|}{ Total $N=231$} & \multirow[b]{2}{*}{$\%$ Yes } \\
\hline & Valid & Missing & \\
\hline $\begin{array}{l}\text { Grandfathered in under new law, so did not have to move } \\
\text { from a residence }\end{array}$ & 222 & 9 & 21.2 \\
\hline $\begin{array}{l}\text { Had to move from a home I owned because it was too close } \\
\text { to a school/day care }\end{array}$ & 229 & 2 & 4.8 \\
\hline $\begin{array}{l}\text { Had to move from a home I rented because it was too close } \\
\text { to a school/day care }\end{array}$ & 227 & 4 & 9.1 \\
\hline $\begin{array}{l}\text { When released from jail, unable to retum home because } \\
\text { too close to school/day care }\end{array}$ & 226 & 5 & 11.7 \\
\hline $\begin{array}{l}\text { Unable to live with supportive family because too close to } \\
\text { school/day care }\end{array}$ & 228 & 3 & 19.5 \\
\hline $\begin{array}{l}\text { Unable to live with family who depend on me because too } \\
\text { close to school/day care }\end{array}$ & 227 & 4 & 28.6 \\
\hline Family members forced to move because of restrictions & 228 & 3 & 12.1 \\
\hline Have become homeless because of residence restrictions & 226 & 5 & 7.8 \\
\hline Landlord refused to rent because a sexual offender & 223 & 8 & 23.8 \\
\hline Landlord refused to renew lease because a sexual offender & 222 & 9 & 8.2 \\
\hline $\begin{array}{l}\text { Found it difficult to secure housing that wasn't too close to } \\
\text { school/day care }\end{array}$ & 225 & 6 & 32.9 \\
\hline Have suffered emotionally because of housing restrictions & 225 & 6 & 47.6 \\
\hline Have suffered financially because of housing restrictions & 224 & 7 & 31.6 \\
\hline $\begin{array}{l}\text { Because of restrictions, I live further from employment } \\
\text { opportunities }\end{array}$ & 223 & 8 & 24.2 \\
\hline $\begin{array}{l}\text { Because of restrictions, I live further from social services } \\
\text { and/or mental health treatment }\end{array}$ & 223 & 8 & 13.0 \\
\hline $\begin{array}{l}\text { Because of restrictions, I live further from supportive family } \\
\text { and/or friends }\end{array}$ & 221 & 10 & 24.2 \\
\hline
\end{tabular}

\section{Implications for Recidivism}

Respondents were also asked two open-ended questions as part of the survey. The first question asked, "Do you think that housing restrictions help prevent you from reoffending?" The majority of respondents (151) answered "no" and only 29 indicated "yes." More than half (166) of respondents provided more than a simple yes=no response to this question. Nearly all (23= 26) of the respondents who provided a yes answer noted that the current restrictions limit access to children or keep them focused on the goals of treatment. Examples of statements included, "won't be tempted," "less access to children," "without direct visibility of a school=children, I can easily avoid bad thoughts and images," "I stay further away from areas where children may be." 
TABIE 3 Sexual Offenders' Perceptions of Residency Restrictions

\begin{tabular}{lccc}
\hline & \multicolumn{2}{c}{ Total $N=231$} & \\
\cline { 2 - 3 } Item & Valid & Missing & $\%$ Yes \\
\hline $\begin{array}{l}\text { I am more able to manage risk factors because I cannot } \\
\quad \text { live near a school/day care. }\end{array}$ & 218 & 13 & 28.1 \\
$\begin{array}{l}\text { Residence restrictions are effective in limiting my access } \\
\quad \text { to children. }\end{array}$ & 218 & 13 & 31.6 \\
$\begin{array}{l}\text { I think residence restrictions help prevent me from } \\
\quad \text { reoffending. }\end{array}$ & 221 & 10 & 22.1 \\
$\begin{array}{l}\text { I think residence restrictions help protect children from } \\
\quad \text { sexual offenders. }\end{array}$ & 219 & 12 & 35.9 \\
$\begin{array}{l}\text { If I really wanted to reoffend, I would be able to do so } \\
\text { despite restrictions. }\end{array}$ & 214 & 17 & 74.5 \\
$\begin{array}{l}\text { Do you think housing restrictions help prevent you from } \\
\text { reoffending? }\end{array}$ & 180 & 51 & 14.3 \\
$\begin{array}{l}\text { Would any residential restrictions prevent you from } \\
\text { reoffending? }\end{array}$ & 162 & 69 & 11.7 \\
\hline
\end{tabular}

Note. The last two questions listed here were open-ended questions.

The majority of the respondents' (140) comments did not support the use of residency restrictions to deter reoffending. These "no" comments fell into four general categories: (a) the fallacy of stranger danger; (b) the offenses did not involve direct contact with children; (c) opportunity abounds= kids are everywhere; and (d) restrictions don't matter=personal autonomy. A minority of respondents $(9=140)$ spoke directly about the erroneous belief that most sexual offenders are strangers and restricting where they live will also restrict their reoffending behavior. One respondent noted, "I offended against a grandchild. The public is at no risk." Another stated, "My offense was in my own home with a family member, as most sex offenses are." Another claimed, "Most offenders have not gone out to find a victim. Most victims are known by the offender."

Another minority of respondents $(13=140)$ noted that their offenses were Internet related or their victims were adults, yet they were subject to the same residency restrictions as child sexual offenders. Examples of these responses included, "My offense was child porn on the Internet," "Because little kids are not my desire so it's foolish to put me in this situation," and "I have no desire or history of sex acts with minors." Another offender noted, "My offense was possession of child pornography. It involved no interaction with children. My issue is computer usage not housing."

Approximately $17 \%$ of respondents $(24=140)$ opined that residency restrictions were not an effective tool for preventing reoffending behavior because opportunity abounds in society. One respondent stated, "There are kids everywhere. This rule makes people feel safer, but it's not logical". Another noted, "Because children are everywhere and so is the possibility for someone to be alone with a child." Others stated, "Opportunity always presents 
itself regardless of where you live such as at places (stores, fast food, etc.)," and "The reality is that people-including children-are everywhere, not just restricted areas."

Of respondents, $57 \%(80=140)$ specifically stated that residency restrictions were not a deterrent and if they wanted to reoffend, they would.

One noted:

Although I obey the restrictions, you could easily find other places to offend if you wanted. I think it's smart to have some restrictions-but they would be easy to break if you were thinking deviantly and really wanted to.

Others made the following comments: "Housing restrictions have no impact on whether or not I would reoffend," "Where I live does nothing to prevent my possibility of reoffending," "If I wanted to reoffend I'll go where children are anyway," "If I had it in my mind to reoffend I would reoffend. Restrictions do not help prevent reoffenders," and "With my ability to have mobility the opportunity to reoffend is always present. Housing restrictions have no effect on whether or not someone reoffends."

The second question asked, "Would any residency restrictions prevent you from reoffending?" The majority (135) provided a "no" response to this question and 26 responded "yes." Fewer respondents (69) provided a written response to this question. Twenty-four respondents (35\%) noted an affirmative response; however half (12) of them echoed current restrictions. One offender noted, "The primary mandatory restrictions are excellent in keeping me from reoffending." Another stated, "All the basic restrictions." Four offenders mentioned that only prison or house arrest would succeed in preventing reoffending. One offender stated, "The only residential restriction would be if I was in jail." Other offenders (6) believed implementing curfews, being confined to group homes, or the use of ankle monitors would be beneficial.

Of the offenders, $36(80 \%)$ provided comments centered on the primacy of personal responsibility, rather than residency restrictions, in serving as a deterrent to sexual reoffending behavior. One offender noted, "If someone is really going to do something, no restrictions will stop them. And most offenses are by new offenders who don't have any restrictions." Another stated:

If someone wants to commit any crime, they are going to do it, regardless of the restrictions within the home. More focus needs to be on educating and treatment of offenders, rather than figuring out more laws and restrictions to keep offenders caged up.

In addition to questioning the efficacy of residency restrictions, one offender wrote:

I do not think housing restrictions prevent anyone from offending. I believe the housing restrictions are a way legal officials try to make people feel safe, but ultimately all they do is make life even harder for everyone by creating more vacant homes, placing offenders in new neighborhoods with people who do not know them, and adding to the 
long list of rules they must adhere to or face the consequences. My opinion is that if the restrictions on housing weren't in place offenders may actually have a better chance at changing their lives for the better.

Three offenders also noted the importance of treatment. One stated, "It's ALL about treatment." Another noted, "Treatment=therapy would. The problem is one, not the location."

\section{DISCUSSION}

The purpose of this research was to assess the experiences and perceptions of registered sexual offenders in North Carolina. The demographic characteristics of the offenders in this study are similar to those in other studies of adult sexual offenders and residency restrictions (Levenson \& Cotter, 2005; Levenson, Brannon, Fortney, \& Baker, 2007; Levenson et al., 2007; Levenson, 2009). Sexual offenders are a difficult population to access. Although random sampling techniques were not utilized, the number of respondents allows the researchers to draw tentative conclusions about the consequences of residency restrictions, particularly in North Carolina. Further, the composite picture yielded from similar research in various states (Minnesota Department of Corrections, 2003, 2007; Levenson \& Cotter, 2005; Tewksbury, 2005; Levenson, 2008, 2009; Ohio State University, 2009; Zandbergen, Levenson, \& Hart, 2010) amplifies the need to assess the current policies regarding the efficacy of sexual offender residency restrictions.

The authors wish to offer other, possibly more effective policies and programs with which to address the management of sexual offenders in North Carolina. In response to significant social, political, legal and civil issues posed by the unintended consequences of residency restrictions, approximately 26 states have implemented sex offender management boards, task forces, or coalitions to help guide decisions at the policy level (Lobanov-Rostovsky \& McBride-Brown, 2009). These management boards have been charged by state legislatures to establish treatment standards that adhere to best practice models for evaluation and treatment of adult and juvenile sexual offenders. Although mandates of these management boards vary by state, it is widely accepted that their intent is to provide legislators with empirically based data, so that rational and effective policy can be considered and perhaps implemented. Several states have already used such data to inform changes in state policy regarding the community management of adult sexual offenders. One solution was the creation of shared living arrangements (SLAs) in Colorado where sexual offenders reside together. This approach has proven more economically viable, provides a supportive environment and has resulted in reduced recidivism (Colorado Department of Public Safety, 2004, 2008, 2009).

The use of risk assessment research to craft public policy is in its early stages. However, existing policies concerning registration and residency restrictions appear to have mixed results (Zgoba \& Simon, 2005; Sandler, Freedman, \& Socia, 2008; Letourneau, Bandyopadhyay, Sinha, \& Armstrong, 2009; Letourneau, Bandyopadhyay, Armstrong, \& Sinha, 2010; Levenson 
et al., 2010). A number of respondents in the current study indicated that where they live would not influence their decision to reoffend. Findings also suggested a number of respondents subject to residency restrictions, who were prohibited from contact with children, did not have prior hands-on offenses against minors. For example, several respondents indicated, "I have no desire or history of sex acts against minors," and "I am a computer offender." These responses highlight several significant issues: while these restrictions are well intentioned and may appear reasonable, they fail to address the larger question of risk among adult sexual offenders.

Currently, under the North Carolina Sex Offender and Public Protection Registration Programs, offenders' risk level is based on their conviction offense. Eligibility for inclusion on the sex offender registry is based on whether their conviction was a reportable offense as described by the North Carolina Registration Program (North Carolina Sex Offender Registration Program, 2008). This method of determining risk is not empirically based nor does it consider that many offenders are convicted of a crime as part of plea agreements between defense attorneys and prosecutor offices. These convictions often do not fully consider the static and dynamic risk factors unique to each offender (e.g., two offenders may be convicted of the same sexual offense, but one may be higher risk due to factors not known at the time of their plea agreement).

Treatment is not a "one-size-fits-all" approach. The aim of a thorough evaluation, risk assessment, and subsequent treatment, is encouraging sexual offenders to become accountable for other offenses, quite possibly elevating an individual's level of risk. Conversely, some offenders who are apprehended, convicted, and receive treatment actually have a low risk of reoffense (Association for the Treatment of Sexual Abusers, 1996; Zgoba \& Simon, 2005). It is short sighted to lump offenders into a "tiered," or one-size-fitsall classification system that examines only the offender's "reportable" or conviction offense, especially since many are pled down to a lesser offense. More information is necessary in order to obtain a more accurate risk assessment.

Further hampering North Carolina's effort to implement effective policy for adult sexual offenders was the passage of the Adam Walsh Child Protection and Safety Act in July 2006, which established a national system for adult and juvenile sexual offender registration and community notification (Adam Walsh Child Protection and Safety Act, 2006). The Adam Walsh Act also seeks to assess offender risk based on a tiered system that includes offense conviction. This tiered system is not supported by current risk assessment research. Contributing to the issue is the lack of empirical evidence to support that public notification or registration of adult sexual offenders has any effect on the frequency of reoffense (Zandbergen et al., 2010). Perhaps most overreaching in the Act is that juvenile offenders, which account for one third of all known sexual offenders, may be required under federal statute to participate in lifetime registration. There is no research to suggest that placing youthful offenders on a national registry reduces rates of reoffense (Association for the Treatment of Sexual Abusers, 2000; Letourneau et al., 2009; Letourneau et al., 2010). 
At present, while most states have implemented some portion of the Act, many are having difficulty complying with major provisions (Colorado Department of Public Safety, 2008). Highlighting this difficulty, in 2009 Attorney General Eric Holder extended States' compliance with the Act until further study of the Act could be completed. Although portions of the Adam Walsh Act are beneficial, such as implementing a National Sex Offender Registry to help law enforcement track offenders and a national child abuse registry to help child protective service workers run national background checks on prospective foster and adoptive parents, the Act does little beyond these protocols and falls short of significantly reducing real risk to communities.

Moreover, these policies may lead to a false sense of security, which may place the public (particularly children) at risk. All legislative acts geared toward restriction and management of sexual offenders are aimed at offenders who are strangers. These cases, such as the recent Jaycee Duggard case in California in which a sexual offender abducted and for 18 years held captive a victim and fathered children with her, are horrific and often have very tragic outcomes, including child murder. However, they are not representative of the majority of sexual offenders, who are far more likely to be family members or friends=acquaintances of their victims. These cases are also horrific and tragic, but are left out of current policy initiatives. Data shows that $7 \%$ of sexual assaults of children under the age of 12 are committed by strangers. The remaining $93 \%$ are committed by family members $(34 \%)$ or acquaintances (59\%) (Snyder, 2000).

Rather than relying on residency restrictions to seemingly restrict access to children in terms of where an offender lives or works, we must take a more comprehensive approach to the community management of sexual offenders. One way to address this problem is to establish, through the North Carolina legislature, a North Carolina Sex Offender Management Board. This Board would be responsible for informing the legislature on empirically grounded, evidence-based research concerning community safety and sex offender management. The Board would also be responsible for standards for empirically based evaluation, risk assessment, and treatment of adult and juvenile sexual offenders. This board would be comprised of community corrections, treatment and mental health practitioners, victim advocacy, and law enforcement, and would conduct research on sexual offender management for the North Carolina Department of Crime Control and Public Safety. In addition, the board would provide briefs to public officials and to communities to help dispel myths and provide fact-based information and public education that may help communities better protect children.

An important component to a more comprehensive approach to managing sexual offenders in the community is access to effective evidence-based treatment, especially treatment modalities that consider offender risk and responsivity, are skills-based, are structured and flexible, and incorporate prosocial support and strengths-based protocols. Currently, there are several treatment models that have shown effectiveness with sexual offenders. Cognitive behavioral treatment has been demonstrated to have the largest effect in reducing recidivism (Hanson et al., 2002; Lo"sel \& Shmucker, 2005). The self-regulation model of the offense and relapse process and the good lives 
model (Lindsay, Ward, Morgan, \& Wilson, 2007) have also shown promise as effective alternative treatment modalities to historical "relapse prevention" which has been considered by many to be too restrictive and rigid to fit the many offender characteristics. Both of these treatment modalities underscore the need for offender personal responsibility, community accountability, and prosocial support often in the form of designated family members or community mentors who can help support offender accountability.

\section{CONCLUSION}

The data suggest that these well-intentioned federal and state policies effectively target some specific areas to help keep communities safe. They help raise awareness of child sexual abuse and provide for several important national registries to combat child sexual abuse and help effectively track offenders from state to state. Legislators often cite public support as a compelling reason for backing restrictive legislation for sexual offenders. However, public support must be balanced with facts and research on the effectiveness of such policies. Residency restrictions largely target offenders who are strangers. However, the overwhelming majority of sexual offenders are not strangers to their victims. This fact was also supported by the current study in which $75 \%$ of offenders were family members or acquaintances of their victims.

Given the shortcomings of current sexual offender legislation, the researchers propose the formation of a North Carolina Sexual Offender Management Board for more effective and comprehensive community management of adult sexual offenders. In the current economic climate, sexual offender management boards provide a starting point for a more efficient, fiscally sound, and viable solution to a persistent problem. Management boards assist in the oversight and development of best practices for a more comprehensive approach to sexual offender community management. The establishment of best practices would increase collaboration and communication between existing agencies (registration, probation=parole, treatment) to better monitor and assess the effectiveness of monitoring sexual offenders in the community. A more comprehensive approach would also entail the involvement of victim services as well as a public education component. The authors also recognize the need to further research in this area, especially the role treatment plays in the perception of and experiences with residency restrictions.

\section{NOTES}

1. This response rate may be an underestimate. Clinicians provided their best estimates of the number of sexual offenders in group treatment while attending the conference and survey packets were sent based on that estimate. Some clinicians overestimated so enough packets would be available to group members.

2. Portions of this data are briefly discussed in another article. 


\section{REFERENCES}

Adam Walsh Child Protection and Safety Act of 2006, 42 U.S.C. x 16911 et seq.

Adkins, G., Huff, D., \& Stagebery, P. (2000). The lowa sex offender registry and recidivism. Des Moines, IA: Iowa Department of Human Rights.

Agudo, S. E. (2008). Irregular passion: The unconstitutionality and inefficacy of sex offender residency laws. Northwestern University Law Review, 102, 307-341.

Arizona Department of Corrections. (2000). Sex offender recidivism. Retrieved from www.rsova.info/reports/az_sorecidivism1984-1998.pdf

Association for the Treatment of Sexual Abusers. (1996). Position on reducing sexual abuse through treatment and intervention with abusers. Retrieved from http:// www.atsa.com/pptreatment.html

Association for the Treatment of Sexual Abusers. (2000). Position on the effective legal management of juvenile sexual offenders. Retrieved from http://www.

atsa.com/ppjuvenile.html

Bagley, A. L. (2008). An era of human zoning: Banishing sex offenders from communities through residence and work restrictions. Emory Law Journal, 75, 1347-1392.

Baronski, R. (2005). Sex offender sentencing in Washington State: Did community notification influence recidivism? (Document No. 05-08-1202). Olympia, WA: Washington State Institute for Public Policy.

Bonnar-Kidd, K. K. (2010). Sexual offender laws and prevention of sexual violence or recidivism. American Journal of Public Health, 100, 412-419.

Brock, E. (2010). Residency laws send sex offenders "off the grid." American City and County, 125(4), 18.

Bureau of Justice Statistics. (2003). Recidivism of sex offenders released from prison in 1994. Washington, DC: U.S. Department of Justice.

Chajewski, M., \& Mercado, C. C. (2009). An evaluation of sex offender residency restriction functioning in town, county, and city-wide jurisdictions. Criminal Justice Policy Review, 20(1), 44-61.

Colorado Department of Public Safety. (2004). Report on safety issues raised by living arrangements for and location of sex offenders in the community. Denver, CO:

Sex Offender Management Board.

Colorado Department of Public Safety. (2008). White paper on the Adam Walsh Child Protection and Safety Act of 2006. Denver, CO: Sex Offender Management Board. 
Colorado Department of Public Safety. (2009). White paper on use of residence restrictions as a sex offender management strategy. Denver, CO: Sex Offender Management Board.

Grubesic, T., Mack, E., \& Murray, A. T. (2007). Geographic exclusion: Spatial analysis for evaluating the implications of Megan's Law. Social Science Computer Review, 25, 143-162.

Gwyn, M. (2007). Recidivism study. Retrieved from http://www.tbi.state.tn.us/tn_ crime_stats/publications

Hanson, R. K., Gordon, A., Harris, A. J. R., Marques, J. K., Murphy, W., Quinsey, V. L., \& Seto, M. C. (2002). First report of the collaborative outcome data project on the effectiveness of psychological treatment for sex offenders. Sexual Abuse: A Journal of Research and Treatment, 14, 169-194.

Hanson, R. K., \& Morton-Bourgon, K. E. (2005). The characteristics of persistent sexual offenders: A meta-analysis of recidivism studies. Journal of Consulting and Clinical Psychology, 73, 1154-1163.

Harris, A. J. R., \& Hanson, R. K. (2004). Sex offender recidivism: A simple question (No. 2004-03). Ottawa, Ontario, Canada: Public Safety and Emergency Preparedness Canada.

Harrison, B., \& Schehr, R. C. (2004). Offenders and post-release jobs: Variables influencing success and failure. Journal of Offender Rehabilitation, 39(3), 35-68.

Huenke, C., O'Connell, J., Price, S., \& Weidlein-Crist, P. (2007). Recidivism of Delaware adult sex offenders released from prison in 2001. Retrieved from www.sac.omb.delaware.gov

Lane Council of Governments. (2003). Managing sex offenders in the community: A national overview. Eugene, OR: U.S. Department of Justice, Office of Justice Programs.

Letourneau, E. J., Bandyopadhyay, D., Armstrong, K. S., \& Sinha, D. (2010). Do sex offender registration and notification requirements deter juvenile sex crimes? Criminal Justice and Behavior, 37, 553-569.

Letourneau, E. J., Bandyopadhyay, D., Sinha, D., \& Armstrong, K. S. (2009). The influence of sex offender registration on juvenile sexual recidivism. Criminal Justice Policy Review, 20, 136-153.

Levenson, J. S. (2008). Collateral consequences of sex offender residence restrictions. Criminal Justice Studies, 21, 153-166.

Levenson, J. S. (2009). Restricting sex offender residence policy implications. Human Rights: Journal of the Section of Individual Rights and Responsibilities, 36(2), 21-23. 
Levenson, J. S., Brannon, Y. N., Fortney, T., \& Baker, J. (2007). Public perceptions about sex offenders and community protection policies. Analyses of Social Issues \& Public Policy, 7, 137-161.

Levenson, J. S., \& Cotter, L. P. (2005). The impact of sex offender residence restrictions: 1,000 feet from danger or one step from absurd? International Journal of Offender Therapy \& Comparative Criminology, 49, 168-178.

Levenson, J. S., D'Amora, D. A., \& Hern, A. L. (2007). Megan's Law and its impact on community re-entry for sex offenders. Behavioral Sciences and the Law, 25, 587-602.

Levenson, J. S., Letourneau, E., Armstrong, K., \& Zgoba, K. (2010). Failure to register as a sex offender: Is it associated with recidivism? Justice Quarterly, 27, 305-331.

Levenson, J. S., Zgoba, K., \& Tewksbury, R. (2007). Sex offender residence restrictions: Sensible crime policy or flawed logic? Federal Probation, 71(3), 2-9.

Lindsay, W. R., Ward, T., Morgan, T., \& Wilson, I. (2007). Self-regulation of sex offending, future pathways and the good lives model: Applications and problems. Journal of Sexual Aggression, 13(1), 37-50.

Lobanov-Rostovsky, C., \&McBride-Brown, S. (2009, October). So you want (or already have) a management board-now what? Paper presented at the annual meeting for the Association for the Treatment of Sexual Abusers (ATSA), Dallas, TX.

Losel, F., \& Shmucker, M. (2005). The effectiveness of treatment for sexual offenders: A comprehensive meta-analysis. Journal of Experimental Criminology, 1, 117-146.

Meloy, M., Miller, S., \& Curtis, K. (2008). Making sense out of nonsense: The deconstruction of state-level sex offender residence restrictions. American Journal of Criminal Justice, 33, 209-222.

Mercado, C. C., Alvarez, S., \& Levenson, J. (2008). The impact of specialized sex offender legislation on community reentry. Sexual Abuse: A Journal of Research and Treatment, 20, 188-205.

Meredith, T., Speir, J., Johnson, S., \& Hull, H. (2003). Enhancing parole decisionmaking through the automation of risk assessment. Atlanta, GA: Applied Research Services.

Minnesota Department of Corrections. (2003). Level three sex offenders residential placement issues. St. Paul, MN: Author.

Minnesota Department of Corrections. (2007). Residential proximity \& sex offense recidivism in Minnesota. St. Paul, MN: Author.

Mustaine, E. E., Tewksbury, R., \& Stengel, K. M. (2006). Residential location and mobility of registered sex offenders. American Journal of Criminal Justice, 30, 177-192. 
National Conference of State Legislatures. (2006). States with sex offender residency restrictions laws. Denver, CO: Author.

New Jersey State Parole Board. (2007). Report on New Jersey's GPS monitoring of sex offenders. Retrieved from www.state.nj.us/parole/docs/reports/gps.pdf

New York State Division of Probation, \& Correctional Alternatives. (2007). Research bulletin: Sex offender populations, recidivism, and actuarial assessment.

Retrieved from http://theparson.net/so/NYsomgmbulletinmay2007.pdf

Norman-Eady, S. (2007). Sex offender's residency restrictions. Retrieved from www.cga.ct.gov/2007/rpt/2007-R-0380.htm

North Carolina Sex Offender and Public Protection Registration Programs (N.C.G.S x14-208.5-208.45).

Ohio Public Safety. (2007). Report to the Ohio criminal sentencing commission: Sex offenders. Retrieved from www.ocjs.ohio.gov

Ohio State University (2009, March 25). Assessing housing availability under Ohio's sex offender residency restrictions. Columbus, $\mathrm{OH}$ : Author.

Payne, B. K., Tewksbury, R., \& Mustaine, E. E. (2010). Attitudes about rehabilitating sex offenders: Demographic, victimization, and community-level influences.

Journal of Criminal Justice, 38, 580-588.

Sample, L. L., \& Bray, T. M. (2003). Are sex offenders dangerous? Criminology and Public Policy, 3(1), 59-82.

Sample, L. L., \& Bray, T. M. (2006). Are sex offenders different? An examination of rearrest patterns. Criminal Justice Policy Review, 17(1), 83-102.

Sandler, J. C., Freeman, N. J., \& Socia, K. M. (2008). Does a watched pot boil? A time-series analysis of New York state's sex offender registration and notification law. Psychology, Public Policy, and Law, 14, 284-302.

Schiavone, S. K., \& Jeglic, E. L. (2009). Public perception of sex offender social policies and impact on sex offenders. International Journal of Offender Therapy and Comparative Criminology, 53, 679-695.

Schulenberg, J. (2007). Predicting noncompliant behavior: Disparities in the social locations of male and female probationers. Justice Research and Policy, 9(1), 25-57.

Snyder, H. N. (2000). Sexual assault of young children as reported to law enforcement: Victim, incident, and offender characteristics. Retrieved from http://bjs.

ojp.usdoj.gov/content/ pub=pdf=saycrle.pdf

State Department of New York Corrections. (2005). 2001 releases: Three year post-release follow-up. Retrieved from www.theparson.net/so/2001_releses_ three_year_post_release_follow_up_NY.pdf 
Tewksbury, R. (2005). Collateral consequences of sex offender registration. Journal of Contemporary Criminal Justice, 21(1), 67-81.

Tewksbury, R., \& Lees, M. B. (2006). Perceptions of sex offender registration: Collateral consequences and community experiences. Sociological Spectrum, 26, 309-334.

Tewksbury, R., \& Zgoba, K. M. (2010). Perceptions of coping with punishment: How registered sex offenders respond to stress, Internet restrictions, and the collateral consequences of registration. International Journal of Offender Therapy and Comparative Criminology, 54, 537-551.

Valentine, D., \& Huebner, B. (2006). Sex offender recidivism in Missouri and community corrections options. Retrieved from www.mosac.mo.gov

Vasquez, B., Maddan, S., \& Walker, J. (2008). The influence of sex offender registration and notification laws it the United States: A time-series analysis. Crime and Delinquency, 54, 175-192.

White, K. (2008). Where will they go? Sex offender residency restrictions as modern-day banishment. Case Western Reserve Law Review, 59, 161-189.

White-Carns, T., McKelvie, S., \& Cohn, L. (2007). Criminal recidivism in Alaska. Retrieved from www.ajc.state.ak.us

Zandbergen, P. A., \& Hart, T. C. (2006). Reducing housing options for convicted sex offenders: Investigating the impact of residency restriction laws using GIS. Justice and Research Policy, 8(2), 1-24.

Zandbergen, P. A., Levenson, J. S., \& Hart. T. C. (2010). Residential proximity to schools and daycares: An empirical analysis of sex offense recidivism. Criminal Justice and Behavior, 37, 482-502.

Zevitz, R., Crim, D., \& Farkas, M. (2000). Sex offender community notification: Managing high risk criminals or exacting further vengeance? Behavioral Sciences and the Law, 18, 375-391.

Zgoba, K. M., \& Simon, L. M. J. (2005). Recidivism rates of sexual offenders up to 7 years later: Does treatment matter? Criminal Justice Review, 30(2), 155-173.

Zgoba, K., Veysey, B., \& Dalessandro, M. (2010). An analysis of the effectiveness of community notification and registration: Do the best intentions predict the best practices? Justice Quarterly, 27, 667-691. 